\title{
HUBUNGAN PENGETAHUAN AYAH DAN BREASTFEEDING FATHER TERHADAP PEMBERIAN ASI EKSKLUSIF DI WILAYAH KERJA PUSKESMAS MENGWI III
}

\author{
Ni Ketut Ayu Kartini, Ni Ketut Martini, I Made Suwitra \\ Program Studi Kesehatan Masyarakat Universitas Dhyana Pura \\ Email: ayuyukar@gmail.com
}

\begin{abstract}
ABSTRAK
ASI merupakan nutrisi terbaik bagi bayi selama 6 bulan pertama kehidupan mereka. Meskipun demikian praktik pemberian ASI eksklusif masih rendah. Keberhasilan dalam memberikan ASI pada bayi dipengaruhi oleh pentingnya dukungan sosial orang terdekat, terutama dari suami. Pengetahuan mengenai masalahmasalah yang berkaitan dengan menyusui merupakan hal pertama yang harus dimiliki ayah agar dapat memberi pengaruh pada praktik pemberian ASI. Penelitian ini bertujuan untuk mengetahui hubungan antara pengetahuan ayah dan breastfeeding father terhadap pemberian ASI eksklusif di wilayah kerja Puskesmas Mengwi III. Penelitian ini dilakukan di wilayah kerja Puskesmas Mengwi III pada bulan Maret sampai dengan April 2018 terhadap 59 bapak/suami yang memiliki anak umur 6-12 bulan. Penelitian ini menggunakan metode kuantitatif dengan pendekatan studi Cross Sectional, dianalisa secara deskriptif dan bivariat. Analisis bivariat menggunakan uji chi square $(\alpha=0,05)$. Hasil penelitian menunjukkan ada hubungan yang signifikan antara pengetahuan ayah dan breastfeeding father terhadap pemberian ASI eksklusif di wilayah kerja Puskesmas Mengwi III. Dimana hasil uji statistik tentang pengetahuan menunjukkan nilai prevelensi rasio sebesar 5,868 dengan nilai $\mathrm{p}$ value $=0,015$ dan hasil uji statistik tentang breastfeeding father menunjukkan nilai prevalensi rasio sebesar 4,069 dengan nilai $\mathrm{p}$ value $=0,044$.
\end{abstract}

Kata kunci: ASI Ekslusif, Pengetahuan, Breastfeeding Father

\begin{abstract}
Breastmilk is the best nutrition for the babies during their first 6 months, despite knowing the clear benefit of exclusive breastfeeding, the practice exclusive breastfeeding is still low. The Success in providing breastmilk for babies influenced by the importance of social support, especially from husband. The knowledge of breastfeeding issues is a matter for father to have in order to influence the practice of breastfeeding. The aim of the study was to determine the relationship between knowledge and father's role in exclusive breastfeeding practice in Puskesmas Mengwi III. This study was conducted at Mengwi III Public Health Center on Maret until April 2018 of 59 father/husband who had children aged 6-12 months. This research used quantitative method with Cross Sectional study approach, the descriptive and bivariate analysis. Bivariate analysis using chi square test $(\alpha=0,05)$.The results showed significant association between knowledge and father's role as breastfeeding father in exclusive breastfeeding practice in Puskesmas Mengwi III. The results of knowledge show the prevalence ratio 5,868 and $p$ value=0,015. The results of father's role show the prevalence ratio 4,069, $p$ value $=0,044$.
\end{abstract}

Keywords: Exclusive Breastfeeding, Knowledge, Breastfeeding Father

\section{PENDAHULUAN}

Air Susu Ibu (ASI) sebagai makanan terbaik untuk bayi dan nutrisi alamiah, karena mengandung kebutuhan energy dan zat yang dibutuhkan selama 6 bulan pertama kehidupan bayi (Wulandari \& Handayani,2011). Pemberian ASI sejak bayi lahir hingga usia 6 bulan tanpa tambahan cairan lain seperti susu formula, jeruk, madu, air teh, serta tanpa tambahan makanan padat seperti pisang, bubur susu, biskuit, bubur nasi dan nasi tim disebut dengan ASI eksklusif. Pemberian ASI eksklusif dapat memenuhi seluruh kebutuhan gizi bayi serta melindungi bayi dari berbagai penyakit seperti diare dan infeksi saluran pernafasan akut (Kementerian Kesehatan RI, 2010).
ASI mengandung kolostrum yang kaya akan antibody karena mengandung protein untuk daya tahan tubuh dan pembunuh kuman dalam jumlah tinggi sehingga pemberian ASI eksklusif dapat mengurangi risiko kematian pada bayi. Kolostrum berwarna kekuningan dihasilkan pada hari pertama sampai hari ketiga. Hari keempat sampai hari kesepuluh ASI mengandung immunoglobulin, protein dan laktosa lebih sedikit dibandingkan kolostrum tetapi lemak dan kalori lebih tinggi dengan warna susu lebih putih. Selain mengandung zat-zat makanan, ASI juga mengandung zat penyerap berupa enzim tersendiri yang tidak akan menganggu enzim di usus. Susu formula tidak mengandung enzim sehingga penyerapan makanan 
tergantung pada enzim yang terdapat di usus bayi (Depkes RI, 2015).

Tahun 2006 World Health Organization (WHO) mengeluarkan standar pertumbuhan anak yang kemudian diterapkan diseluruh belahan dunia. WHO dan UNICEF merekomendasikan ASI eksklusif selama 6 bulan, menyusui dalam 1 jam pertama setelah melahirkan, menyusui setiap kali bayi mau, dan tidak menggunakan botol atau dot. Di Asia Tenggara capaian ASI eksklusif menunjukkan angka yang tidak banyak perbedaan. Sebagai perbandingan, cakupan ASI eksklusif di India sudah mencapai 46\%, di Philipina 34\%, di Vietnam 27\% dan Myanmar 24\% (Harwono, 2012).

Di Indonesia melalui keputusan Menteri Kesehatan Nomor 450/SK/Menkes/VIII/2004, tanggal 7 April 2004 telah menatapkan tentang pentingnya pemberian ASI eksklusif selama 6 bulan. Capaian ASI eksklusif di Indonesia belum mencapai angka yang diharapkan yaitu sebesar 80\%. Berdasarkan laporan SDKI tahun 2012 pencapaia ASI eksklusif adalah 42\%. Berdasarkan laporan dari Dinas Kesehatan Provinsi tahun 2013, cakupan pemberian asi 0-6 bulan hanyalah 54,3\% (pusdatin,2015). Berdasarkan pusat data dan informasi (pusdatin) kemenkes 2015 menunjukkan cakupan ASI eksklusif baru sebesar 54,3\% dari target $80 \%$. Cakupan pemberian ASI eksklusif mengalami peningkatan walaupun belum sesuai target rencana strategis Kementerian Kesehatan sebesar 80\% (Infodatin,2015).

Berdasarkan data Dinas Kesehatan Provinsi Bali tahun 2016 angka cakupan pemberian ASI eksklusif sebesar $72,8 \%$, dimana provinsi bali masih belum mencapai target nasional yaitu sebesar 80\%. Menurut kabupaten/Kota, hanya terdapat dua kabupaten yang berhasil mencapai target yaitu kabupaten Jembrana sebesar 84,7\% dan kabupaten Gianyar sebesar 80,02\%. Kabupaten Buleleng 61,95\%, Karangasem $69,68 \%$ dan kabupaten Badung 70,29\% yang merupakan tiga kabupaten dengan capaian terendah (DINKES Provinsis Bali,2016).

Berdasarkan data jumlah kelahiran tahun 2016, jumlah angka kelahiran hidup di Kabupaten Badung cukup tinggi yaitu 8.041 jiwa dibandingkan dengan Kabupaten Karangasem sebesar 7.835 jiwa. Jumlah bayi yang diberi ASI eksklusif sebesar 2.030 jiwa (70,39\%). Target pencapaian pemberian ASI eksklusif yang direncanakan oleh Kabupaten Badung yaitu 77\%. Menurut sebaran puskesmas di wilayah Kabupaten Badung terdapat tiga puskesmas sudah mecapai target yaitu Puskesmas Petang I 79,61\%, Puskesmas Abiansemal IV 77,92 \% dan Puskesmas Mengwi II 74,88\%. Puskesmas Mengwi III masih belum mencapai target yaitu $61,02 \%$, dimana jumlah bayi 6 bulan sampai 12 bulan di wilayah kerja Puskesmas Mengwi III sebanyak 118 orang dan yang mendapatkan ASI eksklusif sebanyak 72 orang (DINKES Kabupaten Badung, 2016).

Berdasarkan data Dinas Kesehatan Kabupaten Badung angka pemberian ASI eksklusif dalam tiga tahun terakhir mengalami fluktuasi dan belum mencapai target yang telah ditentukan. Pada tahun 2014 target pemberian ASI eksklusif sebesar $76 \%$ sedangkan pencapaiannya hanya $68,20 \%$. Tahun 2015 pencapaian pemberian ASI eksklusif mengalami peningkatan yaitu sebesar 70,29\% meskipun belum mencapai target yang telah ditentukan yaitu sebesar $77 \%$. Sedangkan tahun 2016 pencapaian pemberian ASI eksklusif mengalami penurunan dari tahun sebelumnya yaitu dari $70,29 \%$ menjadi $55,86 \%$, dimana target pemberian ASI eksklusif tahun 2016 sebesar $77 \%$.

Beberapa faktor yang mempengaruhi inisiasi dan durasi dari pemberian ASI eksklusif dibagi menjadi status kesehatan ibu dan bayi, tingkat pendidikan, keterampilan dan pengetahuan ibu, pekerjaan ibu sehari-hari, dan peran serta dari suami (Breastfeeding Father) dan dukungan dari anggota keluarga yang lain (Evaren,2010). Breastfeeding Father adalah dukungan penuh seorang suami sebagai ayah kepada istrinya agar dapat berhasil dalam proses menyusui. Dukungan sang ayah adalah dukungan yang paling berarti bagi ibu. Ayah dapat berperan aktif dalam keberhasilan pemberian ASI khususnya ASI eksklusif karena ayah turut menentukan kelancaran refleks pengeluaran ASI (Milk Let Down Reflex) yang sangat dipengaruhi oleh keadaan emosi atau perasaan ibu.

Ayah cukup memberikan dukungan secara emosional dan bantuan-bantuan yang praktis (Juherman, 2008). Ayah yang mempelajari ASI dan tatalaksana menyusui sebelum memiliki bayi merupakan langkah mencapai keberhasilan pemberian ASI eksklusif. Anak dari ayah yang memiliki pengetahuan baik mengenai ASI memiliki kemungkinan 1,7 kali untuk mendapatkan ASI eksklusif hingga 1 bulan pertama dan 1,9 kali pada bulan ketiga kehidupannya (Destriatania, 2010).

Menurut Haryono \& Setianingsih (2014), dukungan didapat oleh ibu dari dua pihak, yaitu keluarga dan tenaga kesehatan. Tetapi pengaruh dukungan yang paling besar adalah dukungan kelurga terlebih dari suami. Hal ini dikarenakan suami merupakan keluarga inti dan orang yang paling dekat dengan ibu.

Hal ini sejalan dengan penelitian Aries Wahyuningsih (2015), dukungan keluarga (suami) berhubungan dengan peningkatan keberhasilan 
pemberian ASI pada bayi usia 0-6 bulan di Instalasi Rawat jalan Rumah Sakit Baptis Kediri dan penelitian yang dilakukan oleh Sinubawardani (2015) juga memperkuat bahwa ada hubungan yang signifikan antara pengetahuan dan peran ayah dalam pemberian ASI eksklusif di kelurahan Kemijen kecamatan Semarang Timur kota Semarang. Ayah dengan pengetahuan baik mengenai pemberian ASI berpeluang lebih besar untuk berperan dalam proses pemberian ASI eksklusif .

Peningkatan angka kelahiran di Indonesia semakin meningkat namun, keberhasilan pemberian ASI eksklusif masih belum mencapai target yang diharapkan. Cakupan pemberian ASI eksklusif di wilayah kerja Puskesmas Mengwi III merupakan salah satu puskesmas di wilayah Kabupaten Badung yang cakupannya masih rendah. Keberhasilan dalam memberikan ASI pada bayi dipengaruhi oleh beberapa faktor salah satunya adalah faktor eksternal dimana pentingnya dukungan sosial orang terdekat, terutama dari suami. Pemberian edukasi mengenai peran ayah dalam meningkatan motivasi dan memberikan dukungan sosial kepada ibu dalam proses menyusui, sebagai salah satu upaya promosi dan kesuksesan pemberian ASI eksklusif. Pengetahuan mengenai masalah-masalah yang berkaitan dengan menyusui merupakan hal pertama yang harus dimiliki ayah agar dapat memberi pengaruh pada praktek pemberian ASI, hal ini mendorong peneliti untuk meneliti pengetahuan ayah dan breastfeeding father terhadap pemberian ASI eksklusif di wilayah kerja Puskesmas Mengwi III.

\section{METODE}

Penelitian ini menggunakan jenis penelitian kuantitatif dengan pendekatan cross sectional yaitu suatu penelitian untuk mempelajari dinamika korelasi, dengan cara pendekatan observasi atau pengumpulan data sekaligus pada suatu saat (Notoadmodjo, 2010). Penelitian ini bertujuan untuk mengetahui Mengetahui hubungan antara pengetahuan dan peran ayah sebagai breastfeeding father terhadap pemberian ASI eksklusif di wilayah kerja Puskesmas Mengwi III. Populasi dalam penelitian ini adalah seluruh bayi berumur 6-12 bulan yang terdaftar di puskesmas mengwi III, yaitu sebanyak 118 orang pada tahun 2017. Teknik pengambilan sampel yaitu Non Probability Samples dengan teknik consecutive sampling. Pada Consecutive sampling, setiap responden yang memenuhi kriteria penelitian dimasukkan dalam penelitian sampai kurun waktu tertentu, sehingga jumlah responden yang diperlukan terpenuhi. Sampel minimum yang diambil sebanyak 54 responden. Untuk menghilangkan drop out yang mungkin terjadi, maka penulis menambahkan $10 \%$ dari sampel minimum. Sehingga jumlah sampel yang diambil yaitu sebanyak 59 responden.

Analisis data dilakukan untuk menunjang pembuktian hipotesa dengan menggunakan Analisis Univariat untuk mendapat gambaran distribusi frekuensi dan presentase dari tiap variabel dependent dan independent yang akan diteliti. Analisis bivariat digunakan untuk mengetahui hubungan setiap variabel independent dengan variabel dependent. Uji statistik dalam penelitian ini, digunakan rumus chi square (kai kuadrat) dengan derajat kepercayaan $95 \%$.

\section{HASIL DAN PEMBAHASAN}

\section{Karakteristik responden terhadap pemberian ASI Eksklusif di Puskesmas Mengwi III.}

Karakteristik umur responden di wilayah kerja Puskesmas Mengwi III pada penelitian ini sebagaian besar responden berumur diantara 26 sampai 35 tahun sebanyak 37 orang $(62,7 \%)$, sedangkan yang berumur diatas 36 tahun sebanyak 13 orang $(22,0 \%)$ dan terendah berumur dibawah 25 tahun sebanyak 9 orang $(15,3 \%)$. Karakteristik pendidikan responden diwilayah kerja Puskesmas Mengwi III yaitu, untuk golongan pendidikan pada penelitian ini sebagaian besar responden memiliki pendidikan menengah sebanyak 26 orang $(44,1 \%)$. Sedangkan pendidikan tinggi sebanyak 17 orang $(28,8 \%)$ dan terendah berpendidikan dasar sebanyak 16 orang $(27,2 \%)$. Karakteristik pekerjaan responden di wilayah kerja Puskesmas Mengwi III yaitu untuk golongan pekerjaan pada penelitian ini sebagaian besar responden bekerja sebanyak 59 orang (100\%).

\section{Analisis Univariat}

1.Pengetahuan responden sebagai breastfeeding father terhadap pemberian ASI Eksklusif .

Tabel 1. Tingkat pengetahuan sebagai breastfeeding father

\begin{tabular}{lcc}
\hline Pengetahuan & Jumlah & Persentase (\%) \\
\hline Baik & 43 & 72,9 \\
Kurang & 16 & 27,1 \\
\hline Jumlah & 59 & 100 \\
\hline
\end{tabular}


Berdasarkan tabel dari 59 responden sebanyak 43 responden $(72,9 \%)$ berpengetahuan baik dan sebanyak 16 responden $(27,1 \%)$ berpengetahuan kurang.

2. Peran responden sebagai breastfeeding father terhadap pemberian ASI Eksklusif

Tabel 2. Peran responden sebagai breastfeeding father

\begin{tabular}{lcc}
\hline Peran ayah & Jumlah & Persentase (\%) \\
\hline Baik & 44 & 74,6 \\
Kurang & 15 & 25,4 \\
\hline Jumlah & 59 & 100 \\
\hline
\end{tabular}

Berdasarkan tabel dari 59 responden sebanyak 44 responden $(74,6 \%)$ peran responden baik dan

sebanyak 15 responden $(25,4 \%)$ peran responden kurang.

3. Pemberian ASI Eksklusif di wilayah kerja Puskesmas Mengwi III.

Tabel 3. Pemberian ASI Ekslusif

\begin{tabular}{llcc}
\hline \multicolumn{2}{l}{ Pemberian ASI } & Jumlah & Persentase (\%) \\
\hline Pemberian & Eksklusif & 30 & 50,8 \\
ASI & Tidak Eksklusif & 29 & 49,2 \\
\hline Jumlah & & 59 & 100 \\
\hline
\end{tabular}

Berdasarkan tabel dari 59 responden sebanyak 30

eksklusif dan sebanyak 29 responden $(49,2 \%)$ responden $(50,8 \%)$ menjawab memberikan ASI menjawab tidak memberikan ASI eksklusif.

\section{Analisis Bivariat}

1.Hubungan pengetahuan responden terhadap pemberian ASI Eksklusif.

Tabel 4. Hubungan pengetahuan respon terhadap pemberian ASI Ekslusif

\begin{tabular}{|c|c|c|c|c|c|c|c|c|}
\hline \multirow[t]{4}{*}{ Pengetahuan } & \multicolumn{4}{|c|}{ ASI Eksklusif } & \multicolumn{2}{|c|}{ Total } & \multirow{4}{*}{$\begin{array}{l}\text { OR \& } \\
C I\end{array}$} & \multirow{4}{*}{$\begin{array}{l}p \text { - } \\
\text { value }\end{array}$} \\
\hline & \multirow{2}{*}{\multicolumn{2}{|c|}{$\begin{array}{l}\text { Ya } \\
\text { Memberikan }\end{array}$}} & \multirow{2}{*}{\multicolumn{2}{|c|}{$\begin{array}{l}\text { Tidak } \\
\text { Memberikan }\end{array}$}} & & & & \\
\hline & & & & & & & & \\
\hline & $\mathrm{F}$ & $\%$ & $\mathrm{~F}$ & $\%$ & $\mathrm{~F}$ & $\%$ & & \\
\hline Baik & 26 & 60,5 & 17 & 39,5 & 43 & 100 & & \\
\hline Kurang & 4 & 25 & 12 & 75 & 16 & 100 & & \\
\hline Total & 30 & 50,8 & 29 & 49,2 & 59 & 100 & $\begin{array}{l}4,588 \\
1,268\end{array}$ & 0,015 \\
\hline
\end{tabular}

Berdasaarkan tabel di dapatkan hasil dari 59, mayoritas responden memiliki pengetahuan baik, yaitu 43 responden yang memiliki pengetahuan baik memberikan ASI eksklusif sebesar 60,5\% (26 responden) dan 39,5\% (17 responden) tidak memberikan ASI eksklusif, serta angka terendah pada jumlah respoden yang memilik pengetahuan kurang sebanyak 16 responden yang memberikan ASI eksklusif sebesar 25\% (4 responden) dan $75 \%$ (12 responden tidak memberikan ASI eksklusif.

Hasil uji statistik diperoleh confidence interval dengan lower 1.268 dan upper 16.604 dengan nilai $\mathrm{p}$ value sebesar $0,015<0,05$ maka dapat disimpulkan Ho ditolak karena adanya hubungan yang signifikan antara pengetahuan terhadap pemberian ASI eksklusif di wilayah kerja Puskesmas Mengwi III. Nilai OR 4,588 dengan probability $82 \%$ artinya terdapat hubungan dengan kekuatan positif yang kuat.

Berdasarkan hasil sebaran kuisioner dapat diketahui bahwa mayoritas responden memiliki pengetahuan baik. Hal tersebut dapat disebabkan oleh sebanyak $94,9 \%$ responden mengerti apa yang dimaksud dengan ASI Eksklusif, sebanyak 94,9\% mengerti manfaat pemberian ASI Eksklusif, sebanyak $91,5 \%$ responden paham apa yang akan terjadi apabila bayi tidak diberikan ASI dan sebanyak $89,8 \%$ responden memahami pentingnya ikut serta mendukung ibu dalam melalukan IMD. Sedangkan didapatkan beberapa responden memiliki pengetahuan kurang disebabkan oleh sebanyak $88,1 \%$ responden belum mengerti manfaat pemberian kolostrum (ASI jolong), sebanyak 55,9\% belum mengetahui frekuensi yang tepat dalam menyusui berapa kali serta sebanyak 
$55,9 \%$ belum mengetahui bahaya pemberian susu formula.

2.Hubungan breastfeeding father terhadap pemberian ASI eksklusif.

Tabel 5. Hubungan breastfeeding father terhadap pemberian ASI eksklusif

\begin{tabular}{|c|c|c|c|c|c|c|c|c|}
\hline \multirow{3}{*}{$\begin{array}{l}\text { Peran } \\
\text { (Breastfeeding } \\
\text { father) }\end{array}$} & \multicolumn{4}{|c|}{ ASI Eksklusif } & \multicolumn{2}{|c|}{ Total } & \multirow[t]{3}{*}{$O R \& C I$} & \multirow{3}{*}{$p$-value } \\
\hline & \multicolumn{2}{|l|}{ Ya } & \multicolumn{4}{|c|}{ Tidak } & & \\
\hline & $\mathrm{F}$ & $\%$ & $\mathrm{~F}$ & $\%$ & $\mathrm{~F}$ & $\%$ & & \\
\hline Baik & 19 & 43,2 & 25 & 56,8 & 44 & 100 & & \\
\hline Kurang & 11 & 73,3 & 4 & 26,7 & 15 & 100 & & \\
\hline Total & 30 & 50,8 & 29 & 49,2 & 59 & 100 & $\begin{array}{l}2.131 \\
1.886-5126\end{array}$ & 0,044 \\
\hline
\end{tabular}

Berdasarkan dari 59 responden mayoritas responden memiliki peran (breastfeeding father) baik sebanyak 44 responden dan yang memberikan ASI eksklusif sebesar 43,2\% (19 responden) dan yang tidak berikan ASI eksklusif sebesar 56,8\% (25 responden), sedangakan peran (breastfeeding father) yang kurang sebesar 15 responden yang memberikan ASI eksklusif sebesar 73,3\% (11 responden) serta angka terendah pada responden yang memiliki peran (breastfeeding father) kurang dan tidak memberikan ASI eksklusif sebesar 26,7\% (4 responden).

Hasil uji statistik chi-square diperoleh confidence interval $95 \%$ dengan lower 1.886 dan upper 5.126 dengan nilai $p$-value $=0,044 \leq 0,05$ maka Ho ditolak. Ini berarti terdapat hubungan antara peran responden terhadap pemberian ASI Eksklusif di wilayah kerja Puskesmas Mengwi III. Nilai OR $=2.131$ dengan probability sebesar $68,06 \%$ artinya terdapat hubungan dengan kekuatan hubungan positif yang kuat.

Berdasarkan hasil sebaran kuisioner dapat diketahui bahwa responden memiliki peran baik. Hal tersebut dapat disebabkan oleh sebanyak $88,1 \%$ mencari informasi tentang manfaat ASI, sebanyak $94,9 \%$ ayah tidak setuju dengan pernyataan susu formula lebih baik dibandingkan ASI kepada ibu saat bayi baru lahir, sebanyak $88,1 \%$ ayah mengatakan kepada ibu untuk memberikan ASI eksklusif dan sebanyak 89,8\% ayah mendukung inisiasi menyusui dini segera setelah bayi lahir. Sedangkan didapatkan beberapa responden memiliki peran kurang disebabkan oleh sebanyak $94,1 \%$ responden ayah tidak memberikan informasi tentang ASI eksklusif kepada ibu, sebanyak 55,9\% ayah tidak mendampingi ibu saat menyusui bayi serta sebanyak $55,9 \%$ ayah tidak ikut dalam merawat bayi misalnya memandikan bayi atau membedong bayi dan mengganti popok.

\section{SIMPULAN}

Berdasarkan hasil analisis dan pembahasan terhadap hasil penelitian yang dilakukan pada 59 responden (bapak/suami yang memiliki anak usia

6-12 bulan ) di wilayah kerja Puskesmas Mengwi III, dapat disimpulkan bahwa ada hubungan yang signifikan antara pengetahuan dan breastfeeding father terhadap pemberian ASI Eksklusif di wilayah kerja Puskesmas Mengwi III dikarenakan hasil uji statistik menunjukkan nilai $\mathrm{p}$ lebih kecil dari $\alpha$.

\section{DAFTAR PUSTAKA}

Departemen Kesehatan RI, 2015. Manajemen laktasi: Buku Panduan bagi Bidan dan Petugas Kesehatan di Puskesmas. Jakarta: Dit.gizi masyarakat-Depkes RI

Destriatania S,Juhdhiastuty F, Fatimah.,2010. Sikap Ayah dan Jumlah Anak serta Praktik Air Susu Ibu Eksklusif. Jurnal kesmas.2013;8(5):229-34.

Dinas Kesehatan Kabupaten Badung.2016. Data Cakupan Pemberian ASI Eksklusif Badung.

Dinas Kesehatan Provinsi Bali. 2016. Profil Kesehatan Provinsi. Data Cakupan Pemberian ASI Eksklusif. Available from accesedSeptember.2017(http://diskes.balipro v.go.id/id/PROFIL-KESEHATANPROVINSI-BALI2.)

Evareny L. Peran Ayah Dalam Prktik menyusui. Berita Kedokteran masyarakat.2010;26(4):187-95.

Harnowo,A. 2012. Data UNICEF, Cakupan ASI Eksklusif di negara ASEAN (http://m.detik.com/health/readDiakses:20 November 2017 pukul: 10.00)

Haryono,R.,Setyaningsih,S.2014.Manfaat ASI Eksklusif Untuk Buah hati Anda. Yogyakarta.

Infodatin.2015. Situasi dan Analisis ASI Eksklusif.(http:/www.depkes.go.id/resources/ download/pusdatin/infodatin/infodatin- 
asi.pdf. Diakses 14 November 2017 pukul: 8.24 WITA).

JuhermanYN.2008. Pengetahuan,Sikap, dan Peranan Ayah terhadap Pemberian ASI Eksklusif. Institut Pertanian Bogor.

Kementrian Kesehatan RI.2010. Strategi peningkatan Makanan Bayi dan Anak (PMBA). Jakarta :Kementrian Kesehatan RI.

Notoatmodjo,S., 2010. Metodelogi Penelitian kesehatan, Edisi Revisi. Jakarta :PT. Rineka Cipta.

Sinubawardani, Thatit. 2015. Hubungan Antara Pengetahuan dan Peran Ayah dalam
Pemberian ASI Eklusif di Kelurahan Kemijen Kecamatan Semarang Timur. Skripsi. Fakultas Kedokteran. Universitas Semarag Diponogoro, Semarang.

Wulandari,S.,Handayani,S. 2011. Asuhan Kebidanan Ibu Masa Nifas. Yogyakarta: Gosyen Publishing.

Wahyuningsih, Aries. 2015. Dukungan Keluarga (suami) meningkat Keberhasilan Pemberian ASI pada Bayi Usia 0-6 Bulan. Jurnal Stikes Vol 8. No.1 Juli 2015. 